Zdeněk Uhlír

(Praha)

\title{
O Řečech nedělních a svátečních Tomáše ze Štítného: Problém české a latinské transmise kazatelských textů
}

Kazatelství ve středoevropském historickém kulturním regionu v pozdním středověku, tj. v době asi od druhé poloviny 13. do první poloviny 15. století je specifickým a relativně uzavřeným okruhem jak v českém, tak v polském medievistickém bádání. Třebaže kazatelství bylo rozhodujícím médiem sociální komunikace ve středověku, které mělo značný vliv na lidské jednání v čistě praxeologickém smyslu ${ }^{1}$, a třebaže jednotlivá kázání i celé kazatelské sbírky jsou důležitým pramenem pro poznání středověké mentality, a tím i základem pro antropologickou historii ${ }^{2}$, jeho pramenný význam se dosud většinou spíše nedoceňuje ${ }^{3}$. Je proto velkým přínosem, že v souvislosti s novým vydáním jednoho z nejstarších kazatelských souborů dochovaných v polštině (Kazania świętokrzyskie) ( $^{4}$ prokazuje studium středověkého kazatelství jisté oživení. Svým příspěvkem bych se chtěl do tohoto oživujícího proudu zapojit a věnovat se dílčímu tématu českému, které může sloužit pro polskou oblast jako srovnání, totiž české kazatelské produkci Tomáše ze Štítného a jejímu zapojení do soudobé kazatelské produkce latinské.

${ }^{1}$ Viz. L. von Mises, Lidské jednání, Praha 2006.

${ }^{2} \mathrm{O}$ cestě ke zrodu antropologické historie - srv. napr. A. Gurevič, Historikova historie, Praha 2007. Jakýsi manifest historické antropologie - viz. J.-C. Schmidt, Plädoyer für eine historische Antropologie des Mittelalters, „Frühmittelalterliche Studien“, 38:2004, s. 1-16.

${ }^{3}$ Viz. K. Bracha, Nauczanie kaznodziejskie w Polsce późnego średniowiecza: Sermones dominicales et festivales z tzw. Kolekci Piotra z Mitostawia, Kielce 2006; Z. Uhlír, Středověké kazatelství v českých zemích: nástin problematiky, „Almanach Historyczny“, 7: 2005, s. 57-93 (dostupné z URL: (dostupné z URL: http://digit.nkp. cz/mns/uhlir_kazatelstvi.htm).

${ }^{4}$ Viz. Kazania świętokrzyskie: nowa edycja - nowe propozycje badawcze, wyd. P. Stępień, H. Tchórzewska-Kabata, I. Winiarska-Górska, Warszawa 2009. 
K tématu Štítného kázání je však třeba přičinit předběžnou poznámku. Kazatelství je druh na rozhraní literatury a rétoriky, existuje tudíž víceméně zároveň jak v podobě rukopisného záznamu (zápisu do externí paměti), tak podobě orálního projevu (který se ze středověku nedochoval, protože tehdy neexistovaly technické prostředky pro jeho záznam v mluvené podobě). $\mathrm{V}$ případě kazatelství tedy musíme rozlišovat mezi transmisí záznamů na pamětových médiích a performancí mluveného projevu, jejichž obsah nejen že není shodný, ale obě formy se od sebe více méně odlišují ${ }^{5}$. Ačkoli písemná a ústní podoba existovala v době svého tzv. prvního života v podstatě simultánně, do naší dnešní doby se však dochovala jen podoba podléhající transmisi, nikoli však forma vyznačující se performancí. To významně brání plnému poznání středověkého kazatelství: přímo, třebaže zpravidla také jen útržkovitě, je dochován jen jeden jeho aspekt (písemná transmise, rukopisná tradice), zatímco ten druhý (orální performance) nám je úplně neznám, nebo ve spíše jen výjimečných př́padech znám zprostředkovaně $v$ jiných zápisech. Konečným cílem však přece je postihnout komplexnost transmise a performance zároveň.

Problematika kazatelství je však ještě poněkud složitější. Písemná a ústní podoba se totiž od sebe zhusta odlišovaly jazykem. Zpravidla (i když nikoli vždy a nikoli nutně) byla $\mathrm{v}$ českých zemích $\mathrm{v}$ pozdním středověku písemná podoba kázání latinská, zatímco ústní podoba byla česká. Jen v menším počtu případů byla i ústní podoba latinská; zpravidla to nastávalo v prostředí univerzitním a klášterním, ne však jinde: kázání před laickým auditoriem byla takřka bezvýhradně pronášena v národním jazyce, tzn. česky (a mutatis mutandis to platilo i v jiných národních jazykových okruzích západního křestanstva). Právě tak jen výjimečně byly zápisy jinak než latinsky, tzn. rukopisné záznamy v národních jazycích jsou jen řídké. Zápis, resp. text v národním jazyce byl obvykle pořizován tehdy, když neměl sloužit jako kazatelská pomůcka či př́ručka nebo prostě jako opora pro kazatele, nýbrž tehdy, když byl nejenom zamýšlen, ale také prakticky fungoval jako zbožná četba laiků. Záleželo tedy na funkci využití, nikoli na samotné struktuře textu.

5 K tématu vztahů mezi písemnou a ústní komunikací, jakož i symbolickým chováním a rituály srv. napr. H. Keller, Mediale Aspekte der Öffentlichkeit im Mittelalter: Mündlichkeit - Schrtftichkeit - symbolische Interaktion, „Frühmittelalterliche Studien“, 38:2004, s. 277-286; P. Cammarosano, Scrittura, parola e ritualitŕ nelle ambascerie medievali, „Frühmittelalterliche Studien“, 38:2004, s. 347-353; F.-J. Arlinghaus, Rituelle und referentielle verwendung von Schrift: Textgebrauch im spätmittelalterlichen Köln, „Frühmittelalterliche Studien“, 38:2004, s. 393-413. 
Ostatně takřka veškeré žánrové rozdělení středověkého písemnictví je dáno spíše funkčně než strukturně

Štítného kazatelské dílo - ostatně stejně jako dílo kteréhokoli jiného kazatele, at už známého jménem, nebo anonymního - nelze tudíž studovat v tradičním omezujícím záběru písemnictví, nýbrž je k němu třeba přistupovat komplexně na rovinách literatury (produkce písemně tradovaných artificiálních děl ${ }^{7}$ ), písemnictví (produkce fluidních textü ${ }^{8}$ na pomezí literatury a rétoriky) a slovesnosti (orální performance fluidních textů a/nebo artificiálních děl $)^{9}$. Právě tak $\mathrm{k}$ němu nelze přistupovat $\mathrm{v}$ duchu moderního jazykového pojetí národa, jež je v sociologickém pohledu pojetím lidovým ${ }^{10}$, a jeho zpětného promítnutí do středověku ${ }^{11}$, jak se to odrazilo i v jazykové koncepci dějin české literatury ${ }^{12}$, nýbrž musíme vzít v potaz středověké pojetí politického národa ${ }^{13}$, jakož i jeho odraz v latinsko-česko-německé trojjazyčnosti tehdejšího českého písemnictví a tehdejší české literatury ${ }^{14}$. Je tedy žádoucí srovnávat Štítného české

\footnotetext{
${ }^{6}$ Srv. Z. Uhlír, Literární prameny svatováclavského kultu a úcty ve vrcholném a pozdním středověku, Praha 1996.

${ }^{7}$ Srv. Functional Requirements for Bibliographic Records: Final Report, München 1998.

${ }^{8}$ Viz. napr. J. Bryant, The Fluid Text: A Theory of Revision and Editing for Book and Screen, Ann Arbor 2002; srv. Z. Uhlír, Teorie a metodologie elektronicko-digitálního zpracování rukopisu a hybridní knihovna, Praha 2002; tenże, K významu a souvislostem prípravy dat pro digitalizaci rukopisủ, „Národní knihovna: Knihovnická Revue“, 10: 1999, nr. 2, s. 117-129.

${ }^{9}$ Viz. Orality and Literacy in the Middle Agens: Essays on a Conjunction and Its Consequensces in Honour of D. H. Green, ed. M. China, C. Zouny, Turnhout 2005; Speculum Sermonis: Interdisciplinary Reflections on the Medieval Sermon, ed. G. Donavin, C.J. Nederman, R. Utz, Turnhout 2004; C. Muessig, Preacher, Sermon and Audience in the Middle Ages, Leiden-Boston-Köln 2002. Obecně srv. W.J. Ong, Technologizace slova: mluvená a psaná řčc, Praha 2006.

${ }^{10}$ Viz. F. Kutnar, Obrozenské vlastenectví a nacionalismus: Příspěvek k národnímu a společenskému obsahu češství doby obrozenské, Praha 2003; M. Hroch, Evropská národní hnutí v 19. století: předpoklady vzniku novodobých národỉ, Praha 1986; tenże, Na prahu národní existence: touha a skutečnost, Praha 1999; tenże, V národním zájmu: požadavky a cíle evropských národních hnutí v komparativní perspektivě, Praha 1996; V. Macura, České obrození jako kulturní typ, Praha 1992; tenże, Český sen, Praha 1998.

${ }^{11}$ Viz. J. Slavík, Počátky českého národa, Praha 1947; F. Šmahel, Idea národa v husitských Čechách, České Budějovice 1971.

${ }_{12}$ Viz. J. Hrabák, Ze starší české literatury, Praha 1964.

13 Viz. Z. Uhlî́, Pojem zemské obce v tzv. Kronice Dalimilově jako základní prvek její ideologie, „Folia Historica Bohemica“, 9: 1985, s. 7-32; tenże, Národnostní proměny 13. století a český nacionalismus, „Folia Historica Bohemica“, 12: 1988, s. 143-170.

${ }^{14}$ Viz. Z. Uhlî́, Nově objevený zlomek latinského prekladu Kroniky tak řečeného Dalimila, „Národní Knihovna: Knihovnická Revue“, 16/2: 2005, s. 137-170; tenże, Středoevropský kulturní region ve středověku a raném novověku v českém pohledu, [w:] Čtyři podoby jedné kultury: Spojení rozptýleného obsahu středoevropského písemnictví, Praha 2010, s. 9-33.
} 
kazatelské spisování se sourodým dobovým spisováním latinským, což vzhledem $\mathrm{k}$ dostatku pramenů nebude žádný problém, a německým, což ovšem možné není, protože neznáme žádný pramen, který by to dovoloval, ačkoli české rukopisné sbírky jsou popsány vcelku dobře ${ }^{15}$ a platí to i o rukopisných sbírkách relevantních sousedních zemíl ${ }^{16}$. A samozřejmě nebude od věci provést srovnání Štítného kázání s tehdejším prostředím polským ${ }^{17}$, protože jednota středoevropského historického kulturního regionu - tzn. Mladší Evropy ${ }^{18}$ - je ve středověku a raném novověku zřejmou skutečností.

Tomáš Štítný ze Štítného ${ }^{19}$ se narodil někdy v první polovině třicátých let 14. století na tvrzi Štítné u Žirovnice v jižních Čechách, brzy po založení pražské univerzity na ní studoval, aniž však dosáhl akademického gradu, navrátil se na rodný statek, ale roku 1381 jej pronajal a přesídlil do Prahy, kde někdy v prvním desetiletí 15 . století zemřel. Věnoval se překládání a psaní traktátů o náboženských otázkách, zprvu pouze pro své děti, později také pro širší veřejnost. Jeho tvorba byla dosti rozsáhlá, připisuje se mu (zčásti bezpečně, zčásti hypoteticky) jedenáct děl. Patří mezi ně Sborník vyšehradsky ${ }^{20}$ obsahující překlady Pseudo-Augustina, Davida Augusta, jakož i Hugona ze Svatého Viktora, Kniźky šestery o obecných věcech křestanských (obsažené v první redakci ve Sborníku klementinském a v rozšířené redakci ve Sborníku Vávrově) ${ }^{21}$, Řeči besední (opět ve dvou redakcích) ${ }^{22}$, Řeči nedělní a svátečni ${ }^{23}$, Zjevení svaté Brigity (také ve dvou redakcích) ${ }^{24}$, Knihy naučení krestanského (úplně dochovány ve Sborníku muzejním, neúplně ve Sborníku jezuitském a Sborníku sázavském a v prepracované podobě, doplněné o další překla-

${ }^{15}$ Viz. Průvodce po rukopisných fondech v České republice, t. 1-4, Praha 1995-2004.

16 Viz. Zbiory rękopisów $w$ bibliotekach i muzeach $w$ Polsce, wyd. D. Kamolova, Warszawa 2003.

${ }^{17}$ Srv. napr. Kazania świętokrzyskie: nowa edycja - nowe propozycje badawcze, wyd. P. Stępień, H. Tchórzewska-Kabata, I. Winiarska-Górska, Warszawa 2009; Kazanie na dzień Wszech Świętych (tzw. praskie), wyd. E. Belcarzowa, R. Mazurkiewicz, P. Stępień, W. Twardzik, W. Wydra, Poznań 2008.

${ }_{18}$ Viz. J. Kłoczowski, [TU BRAK OPISU]

${ }^{19}$ Viz. J. Lehár, Tomáš ze Štítného, [[w:]] Lexikon české literatury: Osobnosti, díla, instituce, t. 4/1, Praha 2008, s. 768-771.

${ }^{20}$ Viz. Tomáš ze Štítného, Sborník vyšehradský, ed. F. Ryšánek, Praha 1960.

21 Viz. Tomáš ze Štítného, Knížky šestery o obecných věcech křestanských, ed. K.J. Erben, Praha 1852.

${ }^{22}$ Viz. Tomáš ze Štítného, Řeči besední, ed. M. Nedvědová, Praha 1992; starší edici viz. Tomáš ze Štítného, Besední řeči, ed. M. Hattala, Praha 1897.

${ }^{23}$ Viz. Tomáš ze Štítného, Řeči nedělní a sváteční, ed. J. Straka, Praha 1929.

${ }^{24}$ Viz. Tomáš ze Štítného, Zjevení svaté Brigity v překladu Tomáše ze Štítného, ed. P. Richterová, Praha 2009. 
dy i vlastní práce ve Sborníku opatovickém) ${ }^{25}$, Knižky o hře šachove ${ }^{26}$, Život svaté Alžběty ${ }^{27}$, duchovní román Barlaam a Josafat ${ }^{28}$, jakož i překlady zapsané ve Sborníku Václava z Poříčie. Nutno říci, že Štítného dílo představuje - nejenom na laika - dosti úctyhodný výkon.

Štítný důsledně rozlišoval mezi překlady a vlastními díly. Většina jeho překladů jsou v dnešním pojetí spíše adaptace než věrné překlady, ačli to nezávisí na povaze středověké rukopisné transmise, která ne vždy byla věrná danému znění (trřebaže v některých případech je naopak znění transmitovaného textu i při značném počtu rukopisných záznamů velice stabilní). V př́ípadě Života svaté Brigity ${ }^{29}$ se však zdá, že tento jeho překlad je naopak velice věrný. Je sice pravda, že znění dochovaných rukopisů je oproti latinskému originálu podobně proměněné a proměnlivé, nicméně pokus o rekonstrukci archetypu, který editorka podnikla nejspíše svědčí o tom, že text, který vzešel ze Štítného pera, byl opravdu přesným překladem. Na tom, že jeden autor postupoval př̀i překládání různých spisů zcela odlišným způsobem, nemusí být nic podivného, protože to běžně vidíme i jinde ve středověkém písemnictví. Projevuje se $\mathrm{v}$ tom rétorický styl středověké literatury bez autorů a bez generaci $i^{30}$, který při reprezentaci rozličných látek a témat připouštěl různou míru reprodukce tzv. vlastními slovy, jakož i dovoloval použití metody Zersetzung und Vererbung ${ }^{31}$.

Řeči nedělní a svátečni ${ }^{32}$ se v obecných rysech nevymykají z této základní podoby středověkého písemnictví, ani podstatně nevybočují ze Štít-

25 Viz. Tomáš ze Štítného, Knihy naučení křestanského, ed. A.J. Vrtátko, Praha 1873; ukázky ze Sborníku opatovického viz. J. Stárek, Rukopis opatovický, „Časopis Českého Muzea“, 15: 1841, s. 317-332.

${ }^{26}$ Viz. Tomáš ze Štítného, Knižky o hře šachové a jiné, ed. F. Šimek, Praha 1956; starší edici viz. Tomáš ze Štítného, Knížky o hře šachové, ed. F. Menčík, Praha 1879.

27 Viz. Tomáš ze Štítného, Život svaté Alžběty, ed. J. Kolár, Praha-Litomyšl 2006.

${ }^{28}$ Viz. Tomáš ze Štítného, Barlaam a Josafat, ed. František Šimek, Praha, 1946.

29 Viz. tak Pavlína Richterová, Die Offenbarungen der heiligen Birgitta von Schweden: Eine Untersuchung zur alttschechischen Übersetzung des Thomas von Štítné, Köln-Weimar-Wien 2004; taż, Kirchenkritische Visionen der hl. Birgitta von Schweden und ihre Übersetzung von Thomas von Štítný, [w:] Pater familias: Sborník príspěvkü k životnímu jubileu prof. Dr. Ivana Hlaváčka, ed. Jan Hrdina - Eva Doležalová - Jan Kahuda, Praha 2002, s. 357-379.

${ }^{30}$ Viz. A. Škarka, Literatura bez autorů a bez generací, „Listy Filologické“, 72: 1948, s. 171-176.

${ }^{31}$ Viz. A. Spamer, Über die Zersetzung und Vererbung in den deutschen Mystikertexten, Gießen 1910.

32 Srv. J. Jireček, Řeči nedělní a sváteční, „Časopis Českého Muzea“, 35: 1861, s. 171-175; J. Straka, Štítného Řeči nedělní a sváteční, „Listy Filologické“, 35: 1908, s. 35-40, 130-136, 226-234, 347-359; 36: 1909, s. 35-39, 117-121, 240-151, 450-462; 
ného individuálního spisovatelského stylu. Vzhledem k tomu, že jeho autorské promluvy jsou zde silně stylizované, neodrážejí jeho skutečné osobní výpovědi, ale jsou součástí obecného dobového stylu. Z toho plyne, že Řeči nedělní a sváteční nebyly ústně přednášeny jako skutečné sermones per circulum anni, kterými se zdají být a jejichž formu nesou, nýbrž že byly spíše určeny pro zbožnou četbu laikủ. Můžeme předpokládat, že to byla spíše skupinová hlasitá četba v kroužku osob než tichá individuální četba, i když to žádným způsobem nemůžeme bezpečně doložit. V tom př́padě by Štítného Řeči nedělní a sváteční fungovaly jako collationes, tzn. jako doplnění v kostele reálně předneseného kázání někdy později v kroužku zbožných osob. Můžeme tedy říci, že jejich text je relativně pevným textem artificiálního literárního díla, nikoli fluidním textem běžného věcného spotřebního písemnictví. Řečeno ještě jinak, Štítného Řeči nedělní a sváteční nejsou součástí teologie zvěstování v katolickém pojetí, jako byla všechna reálně přednášená či přednesená kázání, nýbrž jsou populární teologií, tzn. zbožnou literaturou, vzdělavatelským, didakticko-moralistickým dílem. Praktické fungování středověkého kazatelství musíme tedy rozšíriit nad jeho praktickou ústní performanci v souvislosti s bohoslužbou také do této obecnější a méně určité oblasti.

Štítného Řeči nedělní a sváteční kombinují vlastní text s textem převzatým, resp. přeloženým do jediného autorského textu, přičemž textu převzatého, přeloženého či jinak adaptovaného je znčná část, takže $\mathrm{z}$ dnešního pohledu je otázka, zda vủbec můžeme hovořit o samostatném autorském díle; vzhledem ke středověkého pojetí, které připouštělo jak zjevné i skryté citáty, tak aluze to však rozhodně možné je. Přestože tedy takový způsob tvorby nebyl ve středověku neobvyklý, u Štítného je ve srovnání s jinými autory přece jen velmi výrazný, až dominantní prvek receptivnosti. Dnes se - přinejmenším v Polsku - takto postupujícím autorům říká ,xeroxoví intelektuálové“, což má nepochybně silně pejorativní konotaci. Ve středověku to sice nemůžeme brát tak striktně, nicméně v takovém způsobu tvorby nelze nevidět jisté vedlejší účinky, protože jej nelze považovat za obyčejné plagiátorství (jak by to mohlo vypadat podle dnešních měřítek), ale o bezprostřední prolnutí aktivní vlastní tvorby a pasivní akulturace.

37: 1910, s. 99-108, 229-249; tenże, K staročeské literatuře náboženské, „Listy Filologické“, 51: 1924, s. 28-42, 135-146; B. Hanzová, Autorská promluva Tomáše ze Štítného $v$ Řečech nedělních a svátečních, [w:] Varia XVIII. Zbornîk príspevkov z.XVIII. Kolokvia mladých jazykovedcov (Prešov - Kokošovce - Sigord 3.-5.12.2008), ed. M. Ološtiak, M. Ivanová, L. Gianitsová-Ološtiaková, Prešov, 2009, s. 209-213. 
Akulturační receptivnost se netýká všech přebíraných textů, protože všechny biblické citáty je záhodno odtud vypustit. Byly totiž běžnou součástí univerzálního evropského stylu, prostě obvyklým způsobem vyjadřování. Jejich význam je potom spíše jenom sekundární týkající se bud' jejich zapojování do vlastního textu ${ }^{33}$, nebo jejich důležitosti pro specifickou formulaci tématu, a to v souvislosti s argumentacíi ${ }^{34}$. Velký význam pro interpretaci Řečí nedělních a svátečních má však využití citátů, resp. textů nebiblických, kterých Štítný využívá. Signifikantní je už sám jejich okruh: zcela jsou z něj vyloučeni autoři ,noví“, tzn. scholastičtí, kteří se opravdu nevyskytují ani jedinkrát. Rezervoár citátů se výhradně soustředuje na autory patristické. Zajisté to může souviset s liturgickými homiliáři jakožto přirozeným základem patristických textů ${ }^{35}$ a zdrojem pro jejich studium. Nelze $v$ tom však nevidět také přímý záměr Štítného, protože využívání scholastických autorit ve vrcholně a zejména pozdně středověkém kazatelství, jakož i v didakticko-moralistickém písemnictví bylo zcela obvyklé. Ukazuje se však, že Štítný se v tom shoduje s proudem devotio moderna, jakož i s českou předhusitskou a husitskou reformací; typické to bylo např. jak pro Miliče z Kroměříže, tak pro Jana Husa. Výhradní používání patristických a nikoli scholastických autorit tedy výmluvně zařazuje Štítného do kontextu tzv. českého náboženského hnutí, které bylo v tomto ohledu předobrazem české husitské reformace, jakkoli nelze říci, že by z něho česká husitská reformace vyplývala př́imo. Jeho zařazení do tohoto proudu je tedy nejenom časové (což by ve skutečnosti mohlo být jen zdánlivé), ale věcné (což předznamenává těsnější souvislost).

Velice důležité je $\mathrm{v}$ tomto př́ípadě zejména srovnání s Miličem z Kroměříže ${ }^{36}$, o málo starším, ale zhruba tři desítky let dřive zemřelým současníkem Štítného. Ačkoli Milič přirozeně kázal česky, protože se obracel k lidu v sociokulturním významu, tj. k laikům, ruko-

${ }^{33} \mathrm{~V}$ tomto ohledu srv. napr. N. Bray, Deutsche Bibelzitate in den Predigten Meister Eckharts, [w:] Meister Eckhart in Erfurt, hrsg. von A. Speer, L. Wegener, Berlin-New York 2005, s. 409-426.

$34 \mathrm{~V}$ tomto ohledu srv. napr. Z. Uhlír, Determinace Maříka Rvačky na obranu Řehoře XII., „Acta Universitatis Caroline - Historia Universitatis Carolinae Pragensia“, 41/1-2: 2001, s. 177-193.

35 Viz. F.M. Bartoš, Štítný a osudy homiliarre v našich zemích, „Reformační Sborník“", 8: 1941, s. 58-64.

${ }^{36}$ Viz. J. Lehár, Jan Milíč z Kroměř́že, [w:] Lexikon české literatury: Osobnosti, dila, instituce, t. 3/1, Praha 2000, s. 274-276. Srv. P.C.A. Morée, Preaching in the Fourteenth-Century Bohemia: The Life and Ideas of Milicius de Chremsir (+1374) and His Significance in the Historiography of Bohemia, Heršpice 1999. 
pisná transmise jeho kázání je však výlučně latinská. Je to dáno jednak tím, že rukopisné záznamy kazatelství v této době byla ještě naprostou většinou, byt nikoli výhradně latinské, třebaže kázání byla pronášena česky, resp. v národních jazycích vủbec. Mnohem důležitější však je to, že Miličovy kazatelské sbírky, a to jak Abortivus podávající kázání v podobě tematických sermonů, tak zejména Gracie dei podávající kázání v podobě exegetických homilií, v žádném případě nejsou záznamem jím pronesených kázání (at už v jakékoli formě), ani žádnými přípravami pro pronesená kázání. Naopak, jsou to zcela zřetelně vzory, které měly žákům Miličova kruhu předvést, jak má vypadat dokonale a podrobně provedené kázání. Na jejich základě bylo možno zjednodušením a zkrácením (jen hypoteticky lze mluvit o opačném způsobu, to je o prohloubení a prodloužení) vytvořit a posléze přednést kázání vlastní. I Miličova rukopisně dochovaná kázání, a to jak jejich jednotky, tak celé sbírky, jsou artificiálními díly určenými k četbě a vlastně ke studiu; v žádném prrípadě to nejsou záznamy obvyklých fluidních textů běžného kazatelského písemnictví. V tom je - přes rozdílnost jazyka - srovnatelnost se Štítného Řečmi nedělními a svátečními velice vysoká a v zásadě bezproblematická.

Rys receptivnosti je u Miliče ještě výraznějšš než u Štítného. Ve sbírce Gracie dei (která je vnitřně a strukturálně přehlednější než sbírka Abortivus, protože obsahuje exegetické homilie - což je velice důležité, protože žádná s nich dosud nebyla vydána, takže je třeba vycházet přímo $\mathrm{z}$ rukopisů) Milič do značné míry pouze replikuje (někdy zjednodušení) text Catena aurea Tomáše Akvinského s minimálním vlastním autorským textem, který leckdy spočívá jen v úvodu ke kázání, někdy kromě toho je vloženo několik málo spojujících vět. Díky tomu jsou textová transmise i rukopisná tradice Miličových kázání pozoruhodně stabilní a opravdu lze $\mathrm{v}$ tomto případě hovořit $\mathrm{o}$ artificiálních dílech určených ke čtení, tentokrát dokonce k tichému čtení, jak se to předpokládá u studia. Na tom se ukazuje, že fenomén akulturace je v Miličově případě ještě výraznější než v případě Štítného. To vrhá zpětné světlo na tzv. české hnutí náboženské, které tím nabývá zvláštního charakteru, kterému se dosavadní bádání nevěnovalo. Třebaže - oprostíme-li se od nacionalistických předsudků - je možno připustit, že např. Husovo dílo je bud' výrazně závislé na díle John Wylifa, nebo teologicky rozpačité, přece však lze říci, že tzv. české náboženské hnutí se také velice výrazně zakládalo na díle Matěje z Janova, jež vychází z domácích podmínek a předpokladů, a že tedy není pouhým odvarem cizích vzorů a myšlenek, 
přece zde vyvstává potřeba nového zhodnocení, která by zohlednila akulturační receptivnost Miličovu a Štítného, významných osobností stojících u jeho počátků.

Srovnáme-li Štítného Řeči nedělní a sváteční a Miličovy sbírky Abortivus a Gracie dei s torzem starší polské sbírky Kazania świętokrzyskie, zjištujeme výrazný rozdíl. Kazania świętokrzyskie jsou psána jiným stylem a při zpracování svých pramenů a předloh používají jinou techniku, která se blíží obvyklému, průměrnému způsobu, kterým byly ztvárňovány rukopisy scholastického kazatelského písemnictví. V žádném případě nejsou literárním artificiálním dílem, mnohem spíše mají charakter fluidního textu standardního kazatelského písemnictví evropského stř̌edověku. Neváhají využívat tehdy moderní literatury, přičemž mnohdy jde o pouhé aluze, zjevné i skryté citáty se naopak vyskytují jen docela zř́́dka. Kazania świętokrzyskie jsou tak pramenem jiného typu, se Štítným a Miličem je tudíž nelze srovnávat přímo, bez dalších prostředníkủ a bez širšího kontextu. Protože však komparativní textové studium středoevropského středověkého kazatelství, byt jen v nejelementárnější míre, nebylo dosud provedeno, nemáme dostatek podkladů k vyhodnocení. To je dosud desideratum a zůstává to velkou výzvou pro další bádání.

Na druhé straně pozitivní výsledky, které přineslo srovnání Štítného a Miličova stylu, jakož i jejich techniky práce s prameny a předlohami, dovoluje učinit předběžné závěry, které mohou být dále rozvíjeny. Dủležité je, že v obou př́ípadech se jedná o čistou literaturu bez jakékoli souvislosti s praktickou kazatelskou performancí, nemáme-li za ni považovat funkci collationes, kterou mají texty Štítného, či funkci vzorového rezervoáru, již naplňují texty Miličovy. Významná je také receptivnost, který se projevuje $\mathrm{v}$ nadobyčejném používání dlouhých citátů, které zpř́ístupňují myšlenky, jež byly v rozvinutějších zemích tzv. Starší Evropy již běžně zažité, které však v nejrozvinutější v zemích tzv. Mladší Evropy do značné míry působily jako novinka. Nejdůležitější a - upřímně řekněme - také nejobtížněji pochopitelné je však skutečnost, že z toho, co v literárním procesu písemné transmise vidíme jako receptivnost, vznikla inovativnost v kazatelském procesu orální performance, takže se nakonec české země (vedle střední a severní Itálie na jedné a Nizozemska na druhé straně) rozvinuly ve výrazné centrum náboženského života v Evropě druhé poloviny 14. a první poloviny 15. století. Téma transferu idejí mezi receptivností a inovativností se tudíž ukazuje jako velice nosné pro další bádání. Musíme doufat, že tuto perspektivu pochopí více lidí. 


\section{Streszczenie}

\section{Kazania niedzielne i świąteczne Tomaša ze Štitneho O transmisji kaznodziejskich tekstów czeskich i łacińskich}

Autor na przykładzie zbioru kazań niedzielnych i świątecznych Tomaša ze Štitneho przedstawił probłem transmisji tekstów kaznodziejskich pisanych w językach rodzimych i łacińskim. Tomaš Štítny ze Štitneho (1330/35-1400/1410) zajmował się pisaniem i tłumaczeniem tekstów dewocyjnych. Większość tłumaczeń na język czeski stanowią adaptacje niż dokładne przekłady. Jego teksty - Řeči nedělní a sváteční, funkcjonowały jako collationes - dopełnienia kazania. Utwór ten ma charakter kompiłacji tekstu własnego i przekładów, z przewagą tłumaczeń. Autor porównał kazania Stitneho z zbiorami kazań innego czeskiego teologa Jana Milicza z Kromieryża oraz Kazaniami świętokrzyskimi. Wskazał na inny styl, odróżniający Kazania od tekstów czeskich. Postulatem badawczym jest probłem transmisji idei między recepcją a innowacyjnością $\mathrm{w}$ tekstach kaznodziejskich powstałych w Europie Środkowej w późnym średniowieczu.

\section{Summary}

\section{Festival and Sunday Sermons by Thomas of Štítné: On the Transmission of Preaching Texts in Medieval Czech and Latin}

The author draws on the instance of the sermon collection containing sermons for Sundays and saints' feast-days to discuss the issues related to the transmission of preaching texts both in Latin and in the vernacular. Thomas of Štítné (1330/35-1400/1410) is noted as author and translator of numerous devotionał texts, ałthough most of his translations would now be treated rather as adaptations. His Řeči nedělní a sváteční, functioned as collationes, additions to proper sermons. This work is in fact a compiłation of his own and translated matter, with the preponderance of translations. Uhłî́ compares the sermons by Thomas of Štítné with sermon collections by another Czech theologian Jan Mitíč of Kroměříž, and with the Holy Cross Sermons. He points out the differences in the style of the Holy Cross Sermons and the Czech preaching texts.

Uhłîr ałso formulates a research postulate for the future: it is perhaps worth considering the issues related to the transmission of ideas in the latemedievał preaching texts composed in Centrał Europe as acts located between reception and innovation. 